\title{
Efficacy of Acetamiprid Granule against Cotton Aphid on Cucumber Plants by Various Application Methods
}

\author{
Hidemitsu TaKahashI, ${ }^{*}$ Kazuhiko Murahashi, ${ }^{\dagger}$ Tomohiro TaKe, Makoto ASAI ${ }^{\dagger \dagger}$ \\ and Tomio YAMADA ${ }^{\dagger+}$ \\ *Odawara Research Center, Nippon Soda Co., Ltd., Bikuniyama, Sarasina, Bandai, Yama-gun, Fukushima \\ 969-3302, Japan \\ + Agro Products Division, Nippon Soda Co., Ltd., Chiyoda-ku, Ohtemachi, Tokyo 100-8165, Japan \\ ${ }^{+}$Odawara Research Center, Nippon Soda Co., Ltd., Sakabe, Haibara, Shizuoka 421-0412, Japan \\ ${ }^{+{ }^{+}}$Odawara Research Center, Nippon Soda Co., Ltd., Takada, Odawara, Kanagawa 250-0216, Japan
}

(Received January 11, 2001; Accepted March 8, 2001)

\begin{abstract}
The various efficacy of acetamiprid granule against the cotton aphid on cucumber plants according to several different applications such as planting hole and soil-surface applications was investigated. In planting hole application, the uncontrolled-release granule showed excellent efficacy when treated at the center of hole dug in soil as well as when treated uniformly in the hole. In case of soil-surface application, the efficacy of the granule exhibited higher activity against the aphid as the distance between the treated point and the foot of the transplanted seedling became shorter within the distance of 5,10 and 20 $\mathrm{cm}$ from the foot of the seedling. The relationship between the efficacy and distance of treated points was the same as in the uncontrolled-release granule. Besides, the influence of the watering volume on the activity was examined. With planting hole application, the activity with lower watering-volume plots was higher than that with higher watering one within the watering volume designed. On the other hand, with soil-surface application the activity against the aphids was inferior to that with planting hole application. Moreover, the effect of watering volume and kind of soil on the activity of the controlledrelease granule with planting hole application was examined. It was indicated that a relation between the efficacy and watering volume varied by the kind of soil.
\end{abstract}

Key words: acetamiprid, granule, planting hole application, soil-surface application, cotton aphid, cucumber plants.

\section{INTRODUCTION}

Acetamiprid, (E)- $N^{1}\left[(6\right.$-chloro-3-piridyl)methyl $]-N^{2}-$ cyano- $N^{1}$-methylacetamidine, is a novel insecticide invented in 1989 by Nippon Soda Co., Ltd. The compound has a broad insecticidal spectrum and is highly effective against insect pests such as Lepidoptera, Hemiptera, Tysanoptera and Coleoptera. Acetamiprid was found to possess an excellent systemic activity against aphids and the diamondback moth. ${ }^{1-5)}$ In the previous reports, acetamiprid $2 \%$ granule exhibited practicability against the diamondback moth, Pluttella xylostella and the green peach aphid, Myzus persicae. ${ }^{6-8)}$ The granule was designed to improve efficacy against the diamondback moth, and it was effective also against the green peach aphid on cabbage. ${ }^{9)}$ Aphids infest a broad

\footnotetext{
* To whom correspondence should be addressed.
}

range of crops and they are serious pests because they have developed resistance to other commercial insecticides. The fact led to the investigation of the efficacy of acetamiprid granule against the cotton aphids on cucumber plants by planting hole and soil-surface applications.

\section{MATERIALS AND METHODS}

\section{Chemical}

The controlled- and uncontrolled-release granules including $1 \%$ or $2 \%$ acetamiprid were formulated at the Haibara Agricultural Research Laboratory of Nippon Soda Co., Ltd. ${ }^{9)} \quad$ The released time of controlled-release granules was 30.7 and $54.7 \%$ in 24 and 72 hours after application in water. On the other hand, the released time of uncontrolled-release formulation reached $100 \%$

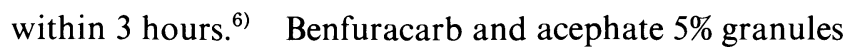
were purchased from commercial source. These formulations were used for the trials. 
Table 1 Physical properties of acetamiprid and standard insecticides. ${ }^{10)}$

\begin{tabular}{llll}
\hline & \multicolumn{1}{c}{ Acetamiprid } & \multicolumn{1}{c}{ Acephate } & \multicolumn{1}{c}{ Benfuracarb } \\
\hline Solubility in water & $4250 \mathrm{mg} / 1\left(25^{\circ} \mathrm{C}\right)$ & $790,000 \mathrm{mg} / 1\left(20^{\circ} \mathrm{C}\right)$ & $8.1 \mathrm{mg} / 1\left(20^{\circ} \mathrm{C}\right)$ \\
Partition coefficient $\left(\log \mathrm{P}_{\mathrm{ow}}\right)$ & $0.8\left(25^{\circ} \mathrm{C}\right)$ & -0.89 & $4.3\left(20^{\left.-22^{\circ} \mathrm{C}\right)}\right.$ \\
Melting point & $98.9^{\circ} \mathrm{C}$ & $82-89^{\circ} \mathrm{C}$ & viscous liquid \\
Vapor pressure & $<1 \times 10^{-3} \mathrm{mPa}\left(25^{\circ} \mathrm{C}\right)$ & $0.226 \mathrm{mPa}\left(24^{\circ} \mathrm{C}\right)$ & $2.66 \times 10^{-2} \mathrm{mPa}\left(20^{\circ} \mathrm{C}\right)$ \\
\hline
\end{tabular}

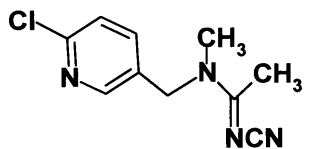

Fig. 1 Chemical structure of acetamiprid.

\section{Insect Pest}

The cotton aphid, Aphis gossypii, which naturally appeared in the field and the plastic house in the Haibara Agricultural Research Laboratory of Nippon Soda Co., Ltd., was tested. Before and after applying the granule, the number of both adults and nymphs of the aphid were counted periodically.

\section{Efficacy of Acetamiprid Uncontrolled-Release Granule with Some Application Methods and Watering Volumes}

Three- to 4-leaf stage seedlings of cucumber raised in a $9 \mathrm{~cm}$-diameter plastic pot stuffed with Kannami soil, which is sandy loam containing $0.1 \%$ organic matter, were prepared for the experiment. These seedlings were transplanted to the field in the plastic house after inoculated with 10 adults of the cotton aphid. The uncontrolled-release granules including $1 \%$ acetamiprid were used for planting hole and soil-surface application tests. As for planting hole application, the granules were applied uniformly in a hole, which was dug $10 \mathrm{~cm}$ in diameter and $5 \mathrm{~cm}$ deep, or at the center of the hole. In case of soil-surface application, the granules were applied on a circle with the radius of 5,10 or $20 \mathrm{~cm}$ around the foot of cucumber after the seedling was transplanted. Watering volume was regulated 2 liter/every 2 days/plant as high-volume plot and 0.5 liter/every 2 days/plant as low volume one after transplanted. The number of aphids infested on the seedling of cucumber was counted on 7, 14 and 21 days after the application. Each test was replicated 4 times. The experiment was conducted at the Haibara Agricultural Research Laboratory of Nippon Soda Co., Ltd., in December, 1990.

\section{Efficacy of Controlled-Release Granule of Acetamiprid Affected by Some Watering Volumes and Soil Kinds with Planting Hole Application}

One-leaf stage seedlings of cucumber which were raised using a plastic pot of $9 \mathrm{~cm}$ in diameter, were provided. The seeds were sown in Kannami and Fujisawa soils, which are clay loam containing $0.1 \%$ and $7.2 \%$ of organic matter respectively, and the seedlings were transplanted to the corresponding soils in the planting pot of $18.6 \mathrm{~cm}$ in diameter when they grew up to one-leaf stage. These pots were kept in a glass house. The granules including $2 \%$ of acetamiprid were applied uniformly in the hole as planting hole application. The watering volume was regulated to 200,400 and $800 \mathrm{ml} /$ every 2 days. Fifteen adult aphids were infested on the second true leaf on 8,16 and 21 days after application, and the efficacy was evaluated 5 days after infestation. Each test was replicated 4 times. The experiment was conducted at the Haibara Agricultural Research Laboratory in February, 1991.

\section{Efficacy of Acetamiprid Controlled-Release Gran- ule in Soil-Surface Application}

One- to two-leaf stage seedlings of cucumber which were raised using a plastic pot of $9 \mathrm{~cm}$ in diameter with Kannami soil were provided. The controlled-release granules including $2 \%$ of acetamiprid were used. The granules were applied on a circle with the radius of 5,10 or $20 \mathrm{~cm}$ around the foot of cucumber after the seedling was transplanted. The watering volume was regulated to $10 \mathrm{~mm} /$ day for 30 minutes. The number of aphids infested on cucumber was counted on 7, 14, 21 and 28 days after the application. The experiment was conducted at the Haibara Agricultural Research Laboratory in July, 1992.

\section{RESULTS AND DISCUSSION}

\section{Efficacy of Acetamiprid Uncontrolled-Release Granule with Some Application Methods and Watering Volumes}

With planting hole application, $0.5 \mathrm{~g}$ of acetamiprid $1 \%$ containing uncontrolled-release granule showed excellent efficacy against the cotton aphids even on the 21 st day after application in both cases when the granules were applied uniformly in the hole and at the center of the hole. From the results of this trial, it was considered that the granule showed excellent efficacy by application at the center of hole as well as uniformly in the hole.

In case of soil-surface application, the granule exhibited higher activity against the aphid as the distance between the treated point and the foot of the seedling became shorter on circles with the radius of 5, 10 and 20 $\mathrm{cm}$ from the foot of seedling. This result suggests that 
the active ingredient released from the granule in the 20 $\mathrm{cm}$ plot moved further than the area of the root elongation (Fig. 2).

Next, the effect of the watering volume on the activity was examined. With planting hole application, the activity in lower watering-volume plots was higher than that with higher watering one. The result shows that the active ingredient released from the granule with higher watering-volume plots moved further behind the range the root can absorb than with lower-watering plots, within watering-volumes designed in the experiment. In other words, with higher watering-volume plots the active ingredient was not properly released to perform the activity against the cotton aphids in an early period after

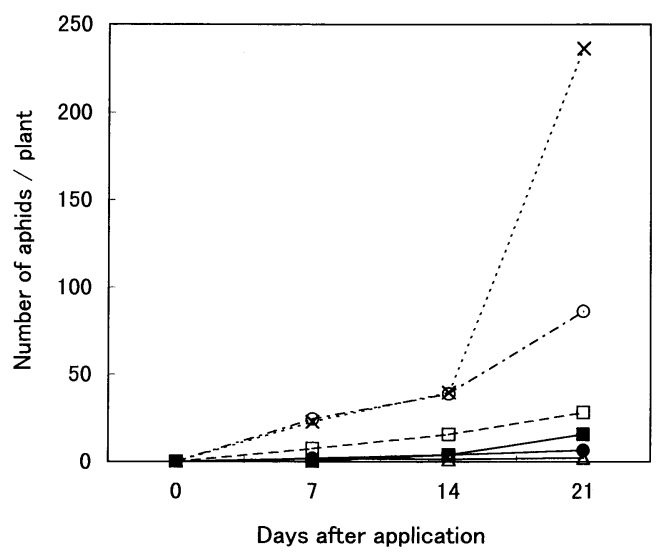

Fig. 2 Efficacy of $0.5 \mathrm{~g}$ acetamiprid $1 \%$ containing uncontrolled-release granule against the cotton aphid by various application methods.

$\longrightarrow$ : planting hole application $\mathrm{A}, \longrightarrow$ : planting hole application $\mathrm{B}, \triangle$ : soil-surface application $\mathrm{A}, \quad-\boldsymbol{-}^{--}$: soil-surface application $\mathrm{B},-\Theta^{--}$: soil-surface application C, ……. : untreated control.

Planting hole application A : applied granule uniformly in a planting hole, planting hole application B : applied granule at the center of a planting hole, soil-surface application $\mathrm{A}$ : applied granule on the circle with the radius of $5 \mathrm{~cm}$ around the foot of seedling, soil-surface application B : applied granule on the circle with the radius of $10 \mathrm{~cm}$ around the foot of seedling, soil-surface application $\mathrm{C}$ : applied granule on the circle with the radius of $20 \mathrm{~cm}$ around the foot of seedling. treatment and the active ingredient seemed wasted because the half-life of acetamiprid in soil is shorter. ${ }^{11}$ Higher watering-volume seems advantageous for giving the activity depending on the level of watering-volume adopted. However, the activity with the lower wateringvolume plots was superior in this trial. On the other hand, with soil-surface application the activity against the aphids was inferior to that with planting hole application. It is supposed that the active ingredient moved horizontally further behind the area the root can absorb, by the short time watering. And the lower wateringvolumes seemed insufficient for the activity of the granule (Fig. 3).

\section{Efficacy of Controlled-Release Granule of Acetamiprid with Some Watering Volumes and Soil Kinds by Planting Hole Application}

Influence of the watering volume and the soil kind on the activity against the cotton aphids with planting hole application was examined. The dosage of acetamiprid

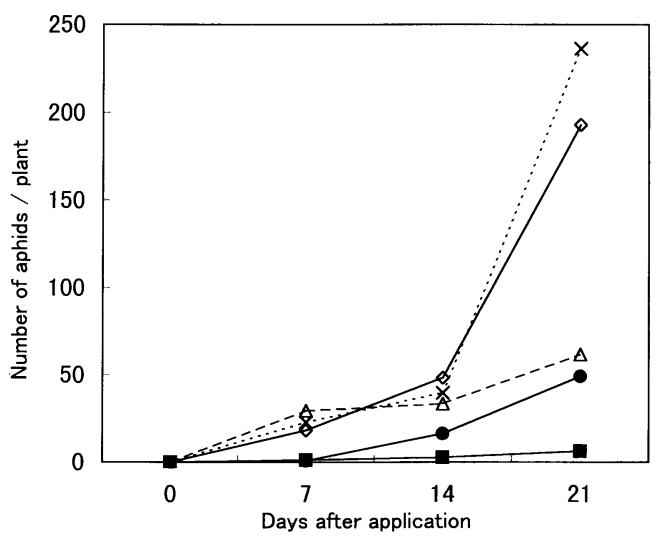

Fig. 3 Efficacy of $0.5 \mathrm{~g}$ acetamiprid $1 \%$ containing uncontrolled-release granule in some application methods and watering volumes against the cotton aphid.

- : planting hole application A, high-volume watering;

$\rightarrow-$ : planting hole application A, low-volume watering;

$\triangle$ : soil-surface application $\mathrm{B}$, high-volume watering;

$\diamond$ : soil-surface application B, low-volume watering; $\times \cdots \cdots \cdot$ : untreated control.

Planting hole application A : applied uniformly at a planting hole, soil-surface application B : applied on the circle at $10 \mathrm{~cm}$ apart from the seedling.

Table 2 Influence of watering volume and the soil kind on the activity of acetamiprid $2 \%$ containing controlled-release granule in planting hole application of cucumber by pot test.

\begin{tabular}{|c|c|c|c|c|c|c|c|}
\hline \multirow{3}{*}{ Compound } & \multirow{3}{*}{$\begin{array}{l}\text { Watering volume } \\
\quad(\mathrm{ml} / 2 \text { days })\end{array}$} & \multicolumn{6}{|c|}{ Number of aphids / plant } \\
\hline & & \multicolumn{3}{|c|}{ Kannami Soil } & \multicolumn{3}{|c|}{ Fujisawa Soil } \\
\hline & & $8^{*}$ & 16 & 21 & 8 & 16 & 21 \\
\hline Acetamiprid & 200 & 0 & 0 & 0 & 1 & 0 & 0 \\
\hline $2 \% \mathrm{G}$ & 400 & 6 & 14 & 6.5 & 2.5 & 0.5 & 3 \\
\hline $0.1 \mathrm{~g} /$ plant & 800 & 1.5 & 50 & 40 & 1 & 6 & 4.5 \\
\hline Untreated & 400 & 51 & 102.5 & 126 & 113.5 & 105 & 150 \\
\hline
\end{tabular}

* : days after application. 
Table 3 Efficacy of acetamiprid 2\% containing controlled-release granule against the cotton aphid on cucumber in soil-surface application.

\begin{tabular}{|c|c|c|c|c|c|c|c|}
\hline \multirow{2}{*}{ Compound } & \multirow{2}{*}{$\begin{array}{l}\text { Dosage } \\
\mathrm{g} / \text { plant }\end{array}$} & \multirow{2}{*}{$\begin{array}{l}\text { Distance*1 } \\
\quad(\mathrm{cm})\end{array}$} & \multicolumn{5}{|c|}{ Number of aphids/plant } \\
\hline & & & $0 * 2$ & 10 & 14 & 21 & 28 \\
\hline \multirow{3}{*}{$\begin{array}{l}\text { Acetamiprid } \\
2 \% \mathrm{G}\end{array}$} & 1 & 5 & 0 & 0 & 0 & 2.7 & 0 \\
\hline & & 10 & 0 & 0.7 & 0 & 0 & 0 \\
\hline & & 20 & 0 & 2.0 & 26.3 & 40.3 & 51.3 \\
\hline \multirow{3}{*}{$\begin{array}{l}\text { Acephate } \\
5 \% \mathrm{G}\end{array}$} & 2 & 5 & 0 & 0.7 & 18.0 & 75 & 29.0 \\
\hline & & 10 & 0 & 1.7 & 7.0 & 48.7 & 21.0 \\
\hline & & 20 & 0 & 15.7 & 149.7 & 166.3 & 89.7 \\
\hline \multirow{3}{*}{$\begin{array}{l}\text { Benturacarb } \\
5 \% \mathrm{G}\end{array}$} & 2 & 5 & 0 & 0 & 3.0 & 15.0 & 109 \\
\hline & & 10 & 0 & 1.0 & 0 & 1.3 & 0.3 \\
\hline & & 20 & 0 & 7.0 & 54.7 & 3.0 & 5.0 \\
\hline Untreated & & & 0 & 6.0 & 66.7 & 233.7 & 157.7 \\
\hline
\end{tabular}

${ }^{* 1}$ : Distance between the applying site and the foot of plant. ${ }^{* 2}$ : Days after application.

was designed to $0.1 \mathrm{~g} /$ plant to compare the efficacy among plots because higher dosage was predicted to exhibit perfect efficacy in all application plots. It is revealed that lower watering-volume with Kannami soil plots exhibited superior efficacy in the levels of 200, 400 and $800 \mathrm{ml}$ per pot, and the efficacy with the $800 \mathrm{ml}$ watering plot was insufficient. On the other hand, the difference in efficacy among the plots of Fujisawa soil was slight. In addition, the efficacy with the $800 \mathrm{ml}$ plot of Fujisawa soil was superior to that of Kannami soil. The efficacy of higher watering volume plots of Kannami soil was inferior to that of Fujisawa soil. This difference in efficacy was supposed to be due to the fact that the moved distance of active ingredient in Kannami soil was longer than that in the Fujisawa soil, since Kannami soil is sandy loam containing $0.1 \%$ organic matter and Fujisawa soil is clay loam containing 7.2\% organic one (Table 2).

\section{Efficacy of Acetamiprid Controlled-Release Gran- ule with Soil-Surface Application}

In the former experiment, it was revealed that the efficacy of acetamiprid uncontrolled-release $1 \%$ granule in soil-surface application declined as the distance between the foot of seedling and granule treating site became longer. Moreover the efficacy of acetamiprid 2\% controlled-release granule in soil-surface application was compared with standard insecticides. The result showed that the efficacy of both acetamiprid $2 \%$ granule $1 \mathrm{~g} /$ plant and acephate $5 \%$ granule $2 \mathrm{~g} /$ plant with the 5 and $10 \mathrm{~cm}$ plots was superior to those with the $20 \mathrm{~cm}$ plot. The controlled-release granule showed the same order in efficacy as the uncontrolled-release one. On the other hand, the efficacy of benfuracarb 5\% containing granule 2 $\mathrm{g} /$ plant with the 5 and $10 \mathrm{~cm}$ plots was superior to that with the $20 \mathrm{~cm}$ plot in an early period of test, but was reversed afterward (Table 3). These results are able to be analyzed from a view point of the physical properties of the compounds. The solubility in water is $4250 \mathrm{ppm}$ for acetamiprid, $650,000 \mathrm{ppm}$ for acephate and $8 \mathrm{ppm}$ for benfuracarb. The active ingredients released from the granules of acetamiprid and acephate, which possessed rather higher solubility in water, moved to the area where the root could absorb them even in case of applying the granule at $5 \mathrm{~cm}$ apart from the plant. On the other hand, for benfuracarb whose solubility in water is low, the active ingredient from the granule applied at $5 \mathrm{~cm}$ from the plant was not enough to exhibit the efficacy 21 days after application even when it showed efficacy in an early period. And the granule of benfuracarb, when treated at $20 \mathrm{~cm}$ apart from the plant, showed efficacy 21 days after the application. It seems that the root of cucumber elongated behind the area where the active ingredient was released from the granule in the plot of 5 $\mathrm{cm}$.

\section{ACKNOWLEDGMENTS}

We thank Mr. Kawana in our Research Center for his valuable suggestions and helpful comment.

\section{REFERENCES}

1) H. Takahashi, J. Mitsui, N. Takakusa, M. Matsuda, H. Yoneda, J. Suzuki, K. Ishimitsu \& T. Kishimoto: Proc. Brit. Crop Protect. Conf. Pests \& Diseases, 89 (1992)

2) M. Matsuda \& H. Takahashi: Plant Prot. 50, 248 (1996)

3) M. Matsuda \& H. Takahashi: Agrochem. Jpn. 68, 20 (1996)

4) H. Takahashi, N. Takakusa, J. Suzuki \& T. Kishimoto: $J$. Pesticide Sci. 23, 193 (1998)

5) T. Yamada, H. Takahashi \& R. Hatano: "Nicotinoid Insecticide and the Nicotinic Acetylcholine Receptor," ed. by I. Yamamoto \& J. E. Casida, Springer, Tokyo, pp. 149-176, 1999

6) H. Takahashi, J. Mitsui, K. Murahashi, M. Asai \& T. Yamada: J. Pesticide Sci. 23, 275 (1998)

7) H. Takahashi, J. Mitsui, M. Yano, T. Take \& T. Yamada: J. Pesticide Sci. 24, 23 (1999)

8) H. Takahashi, J. Mitsui, M. Yano, T. Take, M. Asai \& T. 
Yamada: J. Pesticide Sci. 24, 270 (1999)

9) M. Asai, K. Nishimura \& N. Tanaka (Nippon Soda Co., Ltd.): WO 95-09532 (1995)

10) “The Pesticide Manual Eleventh Edition," ed. by C. D. S. Tomlin, British Crop Protection Council, 1997

11) M. Tokieda, M. Ozawa, S. Kobayashi, K. Gomyou \& M. Takeda: J. Pesticide Sci. 24, 115 (1999)

\section{要 約}

アセタミプリド粒剤の各種施用法によるキュウリ寄 生ワタアブラムシに対する効力

高橋英光，村橋一彦，武 智広 浅井 真, 山田富夫

アセタミプリドの非徐放性粒剂についてキュウリ寄生ワ タアブラムシに対する植穴処理における処理方法の違いに よる効力を比較したところ，粒剤を植穴に均一に処理して も，また植穴の中心にのみ処理してもほぼ同等の効力を得 た. 土㙋表面処理では株元から粒剂処理位置までの距離が $5,10,20 \mathrm{~cm}$ 範囲では, その距離が短いほど高い効力があっ
た.この傾向は徐放性粒剤でも同様であり, 対照薬剤との 比較では，アセフェートと同様であった。一方，ベンフラ カーブでは処理 20 日以降では処理位置 $5 \mathrm{~cm}$ に比べ $20 \mathrm{~cm}$ のほうが優り，前述の 2 薬剤とは傾向を異にした。これは， 薬剤の水溶性の違いによる土壤中での移動の差によるもの と考えられた．灌水量と効力の関係は，植穴処理（植え穴 に粒剂を均一に処理) および土㙵表面処理 (株元から $10 \mathrm{~cm}$ の位置に円状に処理）について多灌水区，少灌水区を設け て効力を検討したところ，植穴処理では少灌水区>多灌水 区, 表面処理では多灌水区>少灌水区で, 総じて植穴処理 > 土壤表面処理であった。植穴処理の多灌水区のアブラムシ に対する効力が少灌水区のそれに劣ったのは，粒剤から溶 出した原体成分が根から吸収できる範囲外へも移動してし まったためと考えられた。さらに，徐放性粒剂を用いて， 灌水量, 土壌の違いによる効力の温室内ポット試験結果か ら, 土壤の違いにより灌水量と効力の関係が異なることが 判明した。 